\title{
PERAN TENAGA ADMINISTRASI DALAM MENINGKATKAN MUTU LAYANAN ADMINISTRASI DI MTs. HIDAYATUL MUHSININ
}

\author{
Abdul Pandi1) \\ STIT Darul Ulum Kubu Raya, Indonesia \\ Email: pandiabdul38@gmail.com¹
}

Dikirim: 19 November 2021

Direvisi: 01 Januari 2022

Dipublikasi: 31 Januari 2022

\begin{abstract}
Abstrak: Peneliti tertarik meneliti ini agar dapat mengetahui: Peran Tenaga Administrasi dalam Meningkatkan Mutu Layanan Administrasi di Mts. Hidayatul Muhsinin Dengan pokok masalah: Kegiatan dan Peran Tenaga Administrasi dalam Peningkatan Mutu Layanan, Hambatan dalam Meningkatkan Mutu Layanan Administrasi dan Strategi dalam Meningkatkan Mutu Layanan Administrasi. Metode yang digunakan dalam penelitian ini adalah metode deskriptif dengan pendekatan kualitatif. Sumber data utama dalam penelitian ini kepala sekolah, Waka Kurikulum, Keuangan Kepala Tata Usaha dan guru yang diperoleh melalui wawancara, observasi, dan dokumentasi. Hasil penelitian ini menunjukkan bahwa 1). Kinerja tenaga administrasi dengan strategi yang dilakukan yaitu memudahkan sistem pembayaran atau biaya yang sudah diterapkan sejak 2008, dan memelihara serta mengelola fasilitas sarana prasana sekolah. Pengintegrasian program dari para tenaga administrasi dengan kegiatan sehari hari di sekolah masih terus berjalan meskipun terdapat beberapa hambatan dalam pelaksanaan. 2). Hambatan-hambatan yang dihadapi sekolah dalam mengelola layanan administrasi yaitu gudang arsip belum optimal, sistem database secara komprehensif belum diterapkan dan penyusunan Rencana Anggaran Pendapatan Belanja Sekolah masih terdapat kesulitan terkait biaya yang tidak dinaikkan, fasilitas yang ada masih terdapat keluhan dari pengguna jasa namun keluhankeluhan tersebut tidak selalu ditangani secara cepat karena terkait jumlah tenaga administrasi. 3). Upaya yang dilakukan untuk menangani beberapa hambatan tersebut ialah memberikan surat pemberitahuan kepada orang tua siswa agar mengumpulkan berkas dengan segera, menaikkan pembayaran biaya sekolah kepada siswa baru untuk menutupi sistem pembiayaan yang tidak dinaikkan, jadi setiap angkatan membayar biaya sekolah dengan biaya yang berbeda, strategi selanjutnya diterapkannya sistem pengontrolan kondisi fasilitas sekolah. Aspek paling penting yang menentukan dalam keberhasilan sebuah satuan lembaga pendidikan yaitu terselenggaranya seluruh aktivitas organisasi sekolah secara efisien. Peranan tenaga administrasi sendiri didalam sekolah sangatlah berarti dalam menunjang kelancaran serta kesuksesan tata administrasi sekolah. Maka dari itu administrasi harus mampu menjalankan tugas dan fungsinya secara baik sehingga diperlukan kompetensi serta keahlian yang mendukung dibidang administrasi.
\end{abstract}

Kata Kunci : Peran Tenaga Administrasi; Mutu Layanan Administrasi 


\begin{abstract}
Researchers are interested in researching this in order to find out: The Role of Administrative Personnel in Improving the Quality of Administrative Services at Mts. Hidayatul Muhsinin With the main problem: Activities and Role of Administrative Personnel in Improving Service Quality, Barriers in Improving Administrative Service Quality and Strategies in Improving Administrative Service Quality. The method used in this study is a descriptive method with a qualitative approach. The main data sources in this study were school principals, Deputy Head of Curriculum, Finance Head of Administration and teachers obtained through interviews, observation, and documentation. The results of this study indicate that 1). The performance of administrative staff with the strategy implemented is to facilitate the payment or fee system that has been implemented since 2008, and maintain and manage school infrastructure facilities. The integration of the program from administrative staff with daily activities at school is still ongoing, although there are several obstacles in implementation. 2). The obstacles faced by schools in managing administrative services are archive warehouses that have not been optimal, a comprehensive database system has not been implemented and the preparation of the School Revenue and Expenditure Budget Plan still has difficulties related to costs that are not raised, existing facilities still have complaints from service users but complaints These complaints are not always handled quickly because they are related to the number of administrative staff. 3). Efforts are being made to overcome some of these obstacles, namely providing a letter of notification to parents to collect files immediately, increasing the payment of school fees to new students to cover the financing system that is not increased, so that each class pays school fees with different fees, the next strategy implementation of a system for controlling the condition of school facilities. The most important aspect that determines the success of an educational institution is the efficient implementation of all school organizational activities. The role of the administrative staff themselves in the school is very meaningful in supporting the smooth and successful administration of the school. Therefore, the administration must be able to carry out its duties and functions properly so that competence and expertise are needed to support the field of administration.
\end{abstract}

Keywords : The role of administrative staff; Administration Service Quality

\title{
Pendahuluan
}

Penyelenggaraan pendidikan dilaksanakan melalui dua jalur, yaitu jalur pendidikan formal (sekolah) dan jalur pendidikan non formal (luar sekolah). Jalur pendidikan sekolah merupakan pendidikan yang diselenggarakan di sekolah melalui kegiatan belajar mengajar secara berjenjang dan berkesinambungan. Jalur pendidikan luar sekolah merupakan pendidikan yang diselenggarakan di luar sekolah melalui kegiatan belajar mengajar yang tidak harus berjenjang dan berkesinambungan. pendidikan formal yang ada di Indonesia terdapat beberapa tingkat atau jenjang pendidikan sesuai dengan tingkatan ilmu yang dipelajari, yaitu terdiri atas pendidikan dasar, pendidikan menengah, dan pendidikan tinggi. ${ }^{1}$

Pendidikan dipercaya sebagai alat untuk mewujudkan mimpi dan harapan dari seorang manusia. Melalui pendidikan manusia menjadi cerdas, memliki keterampilan, sikap yang sopan, dan mampu berinteraksi dengan orang lain. Pendidikan merupakan investasi yang memberi keuntungan sosial dan pribadi yang menjadikan bangsa bermartabat dan menjadikan individunya menjadi manusia yang memiliki derajat dan muliadibandingkan makhluk ciptaan lainnya.

Pendidikan merupakan hal yang sangat penting dalam membentuk baik buruknya pribadi manusia. Menyadari hal tersebut semua satuan pendidikan baik sekolah maupun madrasah memerlukan pendidik dan tenaga kependidikan sesuai kebutuhan dan ketentuan yang berlaku agar dapat melaksanakan kegiatan pendidikan sebagaimana mestinya. Dalam Peraturan Menteri Pendidikan

\footnotetext{
${ }^{1}$ Abu Ahmadi dan Nur Uhbiyati, Ilmu Pendidikan, (Jakarta: PT. Rineka Cipta, 2001), 163.
} 
Nasional Nomor 24 Tahun 2008 pasal 1 ayat 2 "Untuk dapat diangkat sebagai tenaga administrasi sekolah/madrasah, seseorang wajib memenuhi standar tenaga administrasi di sekolah/madrasah yang berlaku secara nasional."

Berkenaan dengan hal tersebut peranan tenaga administrasi sangatlah penting untuk mendukung kelancaran dan kesuksesan tata administrasi sekolah. Dibutuhkan kompetensi dan ketrampilan yang menunjang di bidang administrasi. Keberadaan tenaga administrasi di jenjang pendidikan dasar dan menengah dalam proses pembelajaran sangat diperlukan demi terciptanya sekolah yang bermutu. Sebagai salah satu dalam proses pembelajaran, tugas dan fungsi tenaga administrasi di jenjang pendidikan dasar dan menengah tidak dapat dilakukan oleh pendidik. Hal ini disebabkan: pekerjaannya bersifat administratif yang tunduk pada aturan yang sifatnya khusus, merupakan pekerjaan pelayanan untuk kelancaran proses pembelajaran, memerlukan kompetensi yang berbeda dengan kompetensi yang disyaratkan untuk pendidik dan kadang kala tidak berhubungan secara langsung dengan peserta didik. Di samping itu, sesuai aturan kepegawaian, tugas tenaga administrasi di jenjang pendidikan dasar dan menengah tidak boleh dirangkap oleh tenaga fungsional yang lain.

Tenaga administrasi sekolah merupakan personil yang memiliki peran dan tanggung jawab dalam mewujudkankelancaran kegiatan pendidikan, peran tenaga administrasi sebagai pendukung dan pelayan dalam proses administrasi sekolah. ${ }^{2}$ Karena itu, keterampilan tenaga administrasi merupakan faktor pendukung yang tidak bisa diabaikan dalam pencapaian tujuan sekolah. Tenaga administrasi sekolah ini bertugas sebagai pendukung berjalannya proses pendidikan di sekolah melalui layanan administratif guna terselenggaranya proses pendidikan yang efektif dan efisien di sekolah. Tenaga administrasi pendidikan penting untuk dikaji karena pendidikan merupakan kebutuhan semua orang. Dalam dunia pendidikan diperlukan tenaga administrasi sekolah yang kompeten atau mempunyai kompetensi untuk menunjang keberhasilan pembelajaran di sekolah.

Dari segi fungsi atau aktivitas adalah suatu kegiatan dari organisasi menyesuaikan diri dengan lingkunganyan menentukan struktur kerjanya atas dasar kebutuhan-kebutuhan dalam mencapai tujuan. ${ }^{3}$ Fungsi adalah sekelompok tugas pekerjaan meliputi sejumlah aktivitas yang tergolong pada jenis yang sama berdasarkan sifatnya, pelaksanaanya atau merupakan suatu urutan ataupun secara praktis saling tergantung satu sama lain. ${ }^{4}$ aktivitas ketatausahaan berperan mendukung penyelenggaraan tugas pokok. Namun demikian fungsi sebagai pendukungini tidak mengurangi posisinya yang sangat penting dalam memberikan kontribusi terhadap pencapaian tujuan sekolah. Tanpa dukungan layanan administrasi yang baik dan tertib, mustahil sekolah dapat mencapai visi dan misi yang sudah ditentukan. Dalam proses pembelajaran di sekolah/madrasah terdapat suatu subsistem/komponen yang saling berkaitan. Satu di antara subsistem/komponen tersebut adalah tenaga administrasi sekolah/madrasah di jenjang pendidikan dasar dan menengah. Keberadaan tenaga administrasi tersebut sangat mendukung dalam peningkatan mutu dan pelayanan pendidikan apabila mereka memiliki kualifikasi dan kompetensi minimal sesuai yang disyaratkan.

Administrasi berasal dari bahasa latin yang terdiri dari kata ad dan ministrare. Kata ad mempunyai arti yang sama dengan to dalam bahasa Inggris yang berari ke atau kepada, dan mininistrare sama artinya dengan to serve atau to conduct yang berarti melayani, membantu atau mengarahkan." ${ }^{5}$

Tenaga Administrasi Sekolah (TAS) ialah sumberdaya manusia di sekolah yang tidak terlibat langsung dalam pelaksanaan kegiatan belajar mengajar tetapi berperan mendukung kelancaran proses pembelajaran dan administrasi sekolah."6

\footnotetext{
2 Muniarti AR \&Nasir Isman, Implementasi Manajemen Stratejik dalam Memberdayakan Sekolah. (Bandung: Cipta Pustaka 2009), 129.

${ }^{3}$ Sagala, Syaiful, Kemampuan Profesional Guru dan Tenaga Kependidikan, (Bandung: Alfabeta, 2009), 46.

${ }_{4}^{4}$ The Liang Gie, Administrasi Perkantoran Modern, (Yogyakarta: Liberty,2007), 4.

${ }^{5}$ Ngalim Purwanto, , Administrasi dan Supervisi Pendidikan, (Bandung: Remaja Rosdakarya, 2005), 10.

${ }^{6}$ Anonim, Pengelolaan Laboratorium Fisika Sekolah Menengah Atas, (Jakarta: Direktorat Jenderal Manajemen Pendidikan Dasar dan Menengah, 2007), 103.
} 
Tenaga administrasi sekolah adalah tenaga kependidikan yang bertugas memberikan dukungan layanan administrasi guna terselenggaranya proses pendidikan disekolah. Mereka adalah non teaching staff yang bertugas di sekolah atau sering disebut Tata Usaha (TU). Dalam Kepmendiknas No.053/U/2001 tentang Pedoman Penyusunan Standar Pelayanan Minimal Penyelenggaraan Persekolahan Bidang Pendidikan Dasar dan Menengah dinyatakan bahwa Tenaga Administrasi Sekolah ialah sumber daya manusia di sekolah yang tidak terlibat langsung dalam kegiatan belajar mengajar tetapi sangat mendukung keberhasilannya dalam kegiatan administrasi sekolah.

Sampai sejauh ini belum banyak uraian yang mendalam baik hasil penelitian maupun kajian literatur tentang administrasi pendidikan. Tahap perkembangannya banyak di antara masyarakat selalu terjebak bahwa administrasi pendidikan itu hanya seputar kegiatan tata usaha sekolah dalam arti sempit. Sedangkan kenyataannya satuan pendidikan tidak berdiri sendiri, tetapi ada lembaga lain yang sangat erat kaitannya dengan satuan pendidikan seperti Departemen Pendidikan pada tingkat nasional, Pemerintah Provinsi pada tingkat regional, dan Pemerintahan Kabupaten/Kota pada tingkat daerah, serta institusi kemasyarakatan yang berkepentingan terhadap pendidikan. Semua lembaga-lembaga ini muara dan sasaran kebijakannya adalah sekolah atau satuan pendidikan, karena jika dilihat secara utuh bahwa administrasi pendidikan meliputi lembaga pelayanan sekolah yaitu pemerintah dan lembaga pelayanan belajar yaitu satuan pendidikan. Secara konseptual administrasi pendidikan terdiri dari dua kata yang masing-masing punya pengertian tersendiri yaitu administrasi dan pendidikan. Hal ini menunjukkan bahwa administrasi pendidikan adalah penerapan ilmu administrasi dalam dunia pendidikan atau sebagai penerapan administrasi dalam pembinaan, pengembangan dan pengendalian usaha dan praktek-praktek pendidikan.

Administrasi pendidikan adalah segala usaha bersama untuk mendayagunakan sumber-sumber personil maupun materiil secara efektif dan efisien untuk menunjang tercapainya pendidikan. ${ }^{7}$ Administrasi pendidikan adalah keseluruhan proses yang membuat sumber-sumber personil maupun materiil sesuai dengan yang tersedia dan efektif dalam tercapainya tujuan-tujuan bersama. ${ }^{8}$ Administrasi pendidikan adalah kegiatan bersama dalam bidang pendidikan dengan memanfaatkan semua fasilitas yang tersedia baik personal, material maupun spiritual untuk mencapai tujuan pendidikan. ${ }^{9}$ Administrasi pendidikan seringkali diartikan secara sempit semata-mata kegiatan ketatausahaan seperti menyelenggarakan surat- menyurat, mengatur dan mencatat penerimaan, penyimpanan, mendokumentasikan kegiatan, mempersiapkan laporan, penggunaan dan pengeluaran barang-barang, mengurus neraca keuangan dan sebagainya. ${ }^{10}$ Pengertian demikian ini tidak terlalu salah, karena setiap aspek kegiatan administrasi selalu memerlukan kegiatan yang demikian itu. Hanya saja yang perlu diingat bahwa kegiatan administrasi tidak hanya kegiatan mencatat dalam pengertian tata usaha, tetapi administrasi lebih luas dari itu yang mengandung arti institusional, fungsional, dan sebag suatu proses/kegiatan untuk mencapai tujuan pendidikan yang direncanakan, diorganisasikan, digerakkan dengan menggunakan strategi, dan dilakukan pengawasan.

Mendefinisikan administrasi pendidikan tidak begitu mudah, karena menyangkut pengertian yang luas ditinjau dari berbagai aspek. Pemenuhan standar kualifikasi dan standar kompetensi bagi tenaga administrasi sekolah madrasah di jenjang pendidikan dasar dan menengah dalam jabatan merupakan hak yang wajib dipenuhi oleh penyelenggara sekolah/madrasah. Keberadaan tenaga administrasi sekolah/madrasah di jenjang pendidikan dasar dan menengah atau lazimnya disebut tenaga tata usaha sekolah/madrasah dalam proses pembelajaran sangat diperlukan. Berdasarkan pendapat para ahli, dapat disimpulkan pengertian dari administrasi pendidikan adalah suatu kegiatan kerja sama atau proses

\footnotetext{
${ }^{7}$ Syarif, Ismed dkk, Administrasi Pendidikan Sekolah Dasar, (Jakarta: Roda, 1976), $7 /$

${ }^{8}$ Oteng, Sutisna, Administrasi Pendidikan, (Guru \& Administrasi Sekolab).

(Bandung: Diktat Perkuliahan FKIP-UNPAD, 1979), 2-3.

${ }_{9}^{9}$ Nasution, Berbagai Pendekatan Belajar Dan Mengajar, (Jakarta: Bina Aksara, 1994), 245/

${ }^{10}$ Sagala, Syaiful, Kemampuan Profesional Guru dan Tenaga Kependidikan, (Bandung: Alfabeta, 2009), 37.
} 
pendayagunakan sumber personil dan materiil, yang bergabung dalam suatu lembaga pendidikan demi tercapainya tujuan pendidikan yang telah ditetapkan sebelumnya, agar lebih efektif dan efesien.

Tenaga kependidikan berbeda dengan tenaga personel (tenaga lembaga pendidikan). Lembaga pendidikan merupakan organisasi pelaksana pendidikan dan pengelola penyelenggara pendidikan. ${ }^{11}$ Tenaga pendidikan termasuk personel yang ada di dalam lembaga pendidikan, tetapi tidak semua personel yang ada di dalam lembaga pendidikan, disebut tenaga pendidikan. Tenaga kependidikan adalah tenaga-tenaga (personel) yang berkecimpung di dalam lembaga atau organisasi pendidikan yang memiliki wawasan pendidikan (memahami falsafah dan ilmu pendidikan), dan melakukan kegiatan pelaksanaan pendidikan (mikro atau makro) atau penyelenggaraan pendidikan."

Menurut UUSPN No. 20 Tahun 2003 khususnya Bab I Pasal 1 ayat (5) menyebutkan bahwa tenaga kependidikan adalah anggota masyarakat yang mengabdikan diri dan diangkat untuk menunjang penyelenggaraaan pendidikan. Di mana tenaga kependidikan tersebut memenuhi syarat yang ditentukan oleh Undang-Undang yang berlaku, diangkat oleh pejabat yang berwenang, diserahi tugas dalam suatu jabatan dan digaji pula menurut aturan yang berlaku.

Tenaga kependidikan merupakan seluruh komponen yang terdapat dalam instansi atau lembaga pendidikan yang tidak hanya mencakup guru saja melainkan keseluruhan yang berpartisipasi dalam pendidikan. Dilihat dari jabatannya, tenaga kependidikan dibedakan menjadi tiga, yaitu:

a. Tenaga struktural: Merupakan tenaga kependidikan yang menempati jabatan-jabatan eksekutif umum (pimpinan) yang bertanggung jawab baik langsung maupun tidak langsung atas satuan pendidikan.

b. Tenaga fungsional: Merupakan tenaga kependidikan yang menempati jabatan fungsional yaitu jabatan yang dalam pelaksanaan pekerjaannyamengandalkan keahlian akademis kependidikan.

c. Tenaga teknis kependidikan: Merupakan tenaga kependidikan yangdalam pelaksanaan pekerjaannya lebih dituntut kecakapan teknis operasional atau teknis administratif. ${ }^{12}$

Dari uraian tersebut maka tugas pokok dan fungsi tenaga administrasi adalah kegiatan yang berkaitan dengan melaksanakan urusan ketatausahaan yang meliputi rumah tangga sekolah, perlengkapan, kepegawaian, keuangan, sarana prasarana dan kesiswaan. Oleh karena itu untuk menciptakan mutu layanan dalam administrasi maka tugas dan fungsi tenaga administrasi harus dijalankan dengan baik.

Tata usaha sebagai salah satu unsur dari administrasi merupakan pelayanan terhadap penyelenggaraan usaha kerjasama, yang meliputi kegiatan pencatatan, pengiriman, dan penyimpanan bahan keterangan. ${ }^{13}$ Wujud daripada keterangan-keterangan yang merupakan saran pokok dari kegiatan tata usaha dapat berupa surat-menyurat, formulir, kartu-kartu, daftar-daftar, gambar, foto-foto, dan benda lainnya yang dapat memberi keterangan. Tata usaha dalam arti luas adalah administrasi, administrasi yaitu proses penyeluruhan yang melibatkan semua pihak yang mewujudkan cita- cita bersama, sementara itu administrasi adalah proses kerjasama seluruh kekuatan untuk mewujudkan sekolah yang berkualitas. Sedangkan administrasi pendidikan adalah pembinaan, pengawasan dan pelaksanaan dari segala sesuatu yang berhubungan dengan urusan-urusan sekolah.

Berbicara tentang mutu berarti bicara tentang sesuatu bisa barang atau jasa. Barang yang bermutu adalah barang yang sangat bernilai bagi seseorang. Barang tersebut secara fisik sangat bagus, indah, elegant, mewah, antik, tidak ada cacatnya, awet, kuat, dan ukuran-ukuran lainnya yang biasanya berhubungan dengan kebaikan (goodness), keindahan (beauty), kebenaran (truth), dan idealitas. Hampir semua orang ingin memilikinya tetapi hanya sedikit saja yang dapat menjangkaunya. Karena harganya biasanya sangat mahal. Jasa yang bermutu adalah pelayanan yang diberikan seseorang atau organisasi

\footnotetext{
${ }^{11}$ Mohammad Mustari, Manajemen Pendidikan, (Jakarta: Raja Grafindo Persada, 2014), 215.

12 Ibid. 217.

${ }^{13}$ Mappaenre, Ahmad, Dasar-Dasar Ilmu Administrasi Dan Manajemen. (Makassar: Badan Penerbit Universitas Negeri Makassar,2009), 63.
} 
yang sangat memuaskan, tidak ada keluhan bahkan orang tidak segan-segan untuk memuji dan memberi acungan jempol.

Mutu pendidikan dapat dilihat dari tiga sisi keberhasilanya pendidikan, Yaitu: (1) prestasi, (2) suasana dan (3) ekonomi. ${ }^{14}$ Ada dua standar utama untuk mengukur mutu, (1) standar hasil dan pelayanan (2) standar customer. Indicator ini adalah pelayanan conformance to specification, fitness for purpose or use, zero defect, dan right first time, every time. ${ }^{15}$ Makna yang terkandung adalah bahwa standar hasil pendidikan mencakup spesifikasi penetahuan, keterampilan, dan sikap yang diperoleh melalui pendidian dapat di manfaatkan dalam masyarakat atau dunia kerja.

Dari sudut prosesnya, mutu pendidikan merujuk kepada kegiatan penanganan transformasi masukan-masukan melalui subsistem pemrosesan menjadi keluaran serta hasil-hasil yang berasal dari masukan dan tindakan melalui umpan balik dan evaluasi keluaran. Dalam hal ini tenaga administrasi begitu penting dalam sebuah lembaga formal atau non formal demi mencapai visi, misi dan tujuan sebuah lembaga pendidikan melalui peningkatan mutu layanan administrasi melalui tenaga administrasi pendidikan. Berdasarkan analisis diatas maka peneliti melakukan penelitian tentang Peran Tenaga Administrasi dalam Meningkatkan Mutu Layanan Administrasi di Mts. Hidayatul Muhsinin.

\section{Metode Penelitian}

\section{Pendekatan dan Jenis Penelitian}

Sekilas tentang lokasi penelitian ini dilakukan di MTs. Hidayatul Muhsinin tepatnya Jalan. Perdamaian Komplek Ari Karya Indah IV Desa Pal IX Kecamatan Sungai Kakap Kabupaten Kubu Raya Provinsi Kalimantan Barat. MTs. Hidayatul Muhsinin berdiri dari tahun 2001 sampai saat ini, MTs. Hidayatul Muhsinin di pimpin oleh Kepala sekolah bernama Masruji.

Penelitian kualitatif bisa dilakukan oleh peneliti di bidang ilmu social dan perilaku, juga oleh para peneliti di bidang yang menyoroti masalah yang terkait dengan perilaku dan peranan manusia. ${ }^{16}$ Penelitian kualitatif adalah prosedur penelitian yang bertujuan meneliti suatu masalah dengan cara merumuskan permasalahan lalu meneliti dengan cara mendalam yaitu pengamatan, pencatatan, wawancara, dan terlibat proses penelitian guna menemukan penjelasan berupa pola-pola, deskripsi dan menyusun indikator. ${ }^{17}$ Penelitian kualitatif, teori yang digunakan harus yang diteliti, sebagai dasar untuk merumuskan hipotesis, dan sebagai refrensi menyusun instrument. ${ }^{18}$ Dengan tertulisnya penelitian ini berupa kata-kata tertulis atau lisan dari orang-orang atau pelaku yang dapat diamati, maka termasuk pendekatan kualitatif. Oleh karena itu metode penelitian yang digunakan yaitu penelitian kualitatif. Teknik observasi, wawancara dan studi dokumentasi digunakan untuk pengumpulan data penelitian. Sesuai fokus penelitian maka yang menjadi sumber data dalam penelitian ini adalah Kepala Sekolah, Tenaga Administrasi, beberapa guru, siswa dan orang tua/wali siswa. Selanjutnya untuk mendukung hasil penelitian ini juga dibutuhkan beberapa sumber data dari sekolah seperti data Data primer dan sekunder, data primer adalah sumber data yang langsung memberikan data kepada pengumpul data. ${ }^{19}$ Pengumpulan data primer yang diperoleh dari lapangan ialah tenaga administrasi, kepala sekolah, guru dan siswa, serta fasilitas sekolah sedangkan data sekunder merupakan data yang telah dikumpulkan oleh pihak lain, bukan oleh periset sendiri, untuk tujuan lain, hal ini mengandung arti bahwa periset hanya memanfaatkan data yang sudah ada untuk risetnya. ${ }^{20}$

\footnotetext{
${ }^{14}$ Engkoswara, Kecendrungan kehidupan di Indonesia menjelang tahun 2000 dan Implikasinya terhadap sistem pendidikan, (Jakarta: Intermedia, 1986), 34.

${ }^{15}$ Sallis, Edward, Total Quality Management in Education, London, (British Library Cataloguing in Publication Data, 1933)

16 Anselm Strauss, dkk, Dasar-Dasar Penelitian Kualitatif, (Yogyakarta: Pustaka Belajar 2009), 6.

${ }^{17}$ Alkaf, Nuraida Khalid, Metodologi Penelitian Pendidikan, (Tangerang: Islamic Reserch Publising, 2009), 35.

18 Sugiyono, Metode Penelitian Kuantitatif Kualitatif dan R\&D, (Jakarta: Alfabeta, 2011), 213.

19 Ibit, 225.

20 Sunyoto, Danang, Konsep Dasar Riset Pemasaran dan Perilaku Konsumen, (Yogyakarta: CAPS Center for Academic Publishing. Service, 2014), 42.
} 
Dalam penelitian ini ada beberapa teknik pengumpulan data yaitu wawancara, observasi dan studi dokumenter. ${ }^{21}$ Wawancara digunakan untuk memperoleh data tentang berbagai kegiatan yang dilakukan oleh tenaga kependidikan dalam hal layanan administrasi. Wawancara juga digunakan untuk memperoleh data tentang tanggapan kepala sekolah, tenaga administrasi, guru, siswa, dan orang tua siswa terkait dengan manfaat dari pelayaan yang diberikan oleh tenaga kependidikan dalam hal administrasi sekolah. Dengan demikian yang diwawancarai adalah Kepala MTs. Hidayatul Muhsinin, Kepala Tata Usaha beserta para Stafnya dan 2 guru. ${ }^{22}$ Observasi diartikan sebagai pengamatan dan pencatatan secara sistematik tehadap gejala yang tampak pada objek penelitian. Metode observasi yang digunakan yakni observasi langsung dengan menggunakan panduan pengamatan. Observasi digunakan untuk memperoleh data tentang bentuk program/kegiatan Tenaga Administrasi, dan keadaan para tenaga administrasi dalam hal menunjang peningkatan mutu layanan di MTs.Hidayatul Muhsinin. Studi dokumenter merupakan suatu teknik pengumpulan data dengan menghimpun dan menganalisis dokumen-dokumen. Dokumentasi dilakukan untuk mendapatkan data tentang profil Mts.Hidayatul Muhsinin, profil kepala sekolah, data tenaga administrasi, jenis-jenis layanan administrasi, data rencana/pelaksanaan kegiatan pembinaan tenaga administrasi, data kegiatan layanan administrasi.

\section{Lokasi Penelitian}

\section{Gambaran Umum MTs.Hidayatul Muhsinin}

MTs. Hidayatul Muhsinin sebagai lembaga pendidikan yang dikelola oleh Lembaaga Pendidikan Islam Hidayatul Muhsinin. Mts ini terletak di daerah Desa Pal IX Kecamatan Sungai Kakap Kabupaten Kubu Raya dan berdiri pada tahun 2001. Dari letak geografis berlokasi di lingkungan yang kondusif untuk proses pembelajaran. Akses jalan menuju sekolah ini juga cukup strategis dari arah kota hanya $1 \mathrm{~km}$, Sekolah ini dari tahun ke tahun selalu mengalami perkembangan, baik dari segi kualitas maupun kuantitasnya. Saat ini dipimpin oleh Masruji, sebagai Kepala Sekolah, Yaspi Darmawan Sebagai Waka Kurikulum, Ibu Suhaini, sebagai Keuangan dan M. Amin, sebagai Kepala Tata Usaha.

\section{Kegiatan Tenaga Administrasi MTs.Hidayatul Muhsinin}

Manajemen tenaga kependidikan

merupakan kegiatan yang mencakup penetapan norma, standar, prosedur, pengangkatanpembinaan, penatalaksanaan, kesejahteraan dan pemberhentian tenaga kependidikan sekolah agar dapat melaksanakan tugas dan fungsinya dalam mencapai tujuan sekolah. Diketahui bahwasannya tenaga kependidikan mencakup kepala sekolah, Kepala TU, Wakakur, Bidang Keuangan dan lainnya. ${ }^{23}$ Administrasi pendidikan mencakup bidang bidang garapan yang sangat luas, yaitu:
a. Administrasi tata laksana sekolah
b. Administrasi personel guru dan pegawai sekolah
c. Administrasi murid
d. Supervisi pengajaran
e. Pelaksanaan dan pembinaan kurikulum
f. Pendirian dan perencanaan bangunan sekolah
g. Hubungan sekolah dengan masyarakat. ${ }^{24}$

Tenaga administrasi sekolahmerupakan personil yang memiliki peran dan tanggung jawab dalam mewujudkankelancaran kegiatan pendidikan, peran tenaga administrasi sebagai pendukung dan pelayan

\footnotetext{
${ }^{21}$ Nana Syaodih, Metode Penelitian Pendidikan, (Bandung: Remaja Rosdakarya, 2013), 216.

22 Wawancara, Selasa, 11 Januari 2022, Kepala Masrruji, TU. M. Amin, S.H.I. Guru: Syaifullah, M. Nasir

23 Mohammad Mustari, 2014, Manajemen Pendidikan, Jakarta: Raja Grafindo Persada, 213.

${ }^{24}$ Ngalim Purwanto, 2005, Administrasi dan Supervisi Pendidikan, Bandung: Remaja Rosdakarya, 10.
} 
dalam proses administrasi sekolah. ${ }^{25}$ Kompetensi yang harus dimiliki oleh tenaga administrasi sekolah yaitu dengan tugas pokok dan fungsinya sebagai tenaga administrasi sekolah yang sudah diatur pada Peraturan Menteri Pendidikan Nasional (PERMENDIKNAS) Nomor 24 tahun 2008 tentang Kompetensi Tenaga Administrasi Sekolah. Tenaga administrasi sekolah yang berkompenten juga terkait dengan mutu layanan atau pelayanan prima sehingga dapat menunjang proses pembelajaran yang ada dan pada akhirnya dapat mewujudkan tujuan dari sekolah tersebut. Dilihat dari standar tenaga administrasi sekolah, untuk jenjang Sekolah Menengah Atas (SMA) yaitu kepala tenaga administrasi berkualifikasi berpendidikan S1 dengan program studi yang relevan dengan pengalaman kerja sebagai tenaga administrasi sekolah minimal 4 (empat) tahun atau D3 dan yang sederajat, program studi yang relevan, dengan pengalaman kerja minimal 8 (delapan) tahun. Memiliki sertifikat tenaga administrasi sekolah/madrasah dari lembaga yang ditetapkan oleh pemerintah. Pelaksana urusan terdiri dari administrasi kepegawaian, administrasi keuangan, administrasi sarana dan prasarana, administrasi hubungan masyarakat dan sekolah, administrasi kesiswaan, administrasi persuratan, administrasi kurikulum dan administrasi umum dengan berkualifikasi pendidikan minimal SMA/sederajat. Lambatnya proses administrasi di sekolah seringkali masih dikeluhkan oleh pihak dinas pendidikan dikarenakan kurang tanggapnya pihak sekolah dalam menangani administrasi sekolah yang diperlukan dinas. Proses administrasi sekolah adalah tanggung jawab tenaga administrasi sekolah, keterlambatan dalam proses pengumpulan berkas yang dibutuhkan dinas. Namun di dalam penilitian ini berfokus kepada peranan tenaga administrasi. Dari hasil observasi, wawancara dan studi dokumen yang dilakukan oleh penulis, maka dapat diperoleh data kegiatan tenaga administrasi sebagai berikut:

a. Tenaga administrasi bagian pendidikan \& pengajaran

Kegiatan tenaga administrasi pada bagian ini merupakan salah satu bentuk pelayanan yang diberikan oleh tenaga administrasi untuk membantu tugas guru dalam hal yang berkaitan dengan pembelajaran. Penjelasan tersebut terlihat dari hasil observasi yang dilakukan penulis dan hasil wawancara dengan salah satu guru MTs.Hidayatul Muhsinin bahwa:

"Hasil yang dirasakan kegiatan pembelajaran di dalam kelas terprogam salah satu contohnya ketika pekerjaan yang guru harus mempersiapkan peralatan kelas tetapi pekerjaaan tersebut sudahdilaksanakan oleh pihak tenaga administrasi. ${ }^{26}$

Berdasarkan hasil wawancara tersebut dapat dilihat bahwa kegiatan administrasi yang dilakukan oleh Tenaga Administrasi MTs.Hidayatul Muhsinin cukup membantu guru dalam hal kegiatan belajar mengajar sehingga pekerjaan yang seharusnya dilakukan oleh guru sudah dikerjakan oleh Tenaga Administrasi.

Berdasarkan pemaparan di atas, guru juga terbantu dalam halpengurusan absensi guru maupun siswa. Hal ini sesuai dengan teori yang telah dipaparkan bahwa salah satu kegiatan yang mencakup tenaga kependidikan adalah penatalaksanaan, maka kegiatan tenaga administrasi yang dirasakan oleh salah satu guru tersebut sudah berjalan optimal dan tenaga administrasi mampu melaksanakan tugas dan fungsinya.

b. Tenaga administrasi bidang keuangan

Kegiatan tenaga administrasi pada bagian ini merupakan salah satu bentuk pelayanan yang diberikan oleh tenaga administrasi untuk merancang sistem keuangan segala hal yang berkaitan untuk sekolah, pegawai, maupun siswa. Ibarat bensin bagi sebuah mobil, demikianlah pentingnya biaya atau pembiyaan bagi setiap organisasi. Tanpa biaya yang mencukupi tidak mungkin terjamin kelancaran jalannya suatu organisasi. Demikian pula organisasi seperti halnya dengan lembaga pendidikan atau sekolah. Setiap kebutuhan organisasi, baik personel maupun material, semua

\footnotetext{
${ }^{25}$ Mohammad Mustari, Manajemen Pendidikan, (Jakarta: Raja Grafindo Persada, 2014), 129.
}

${ }^{26}$ Wawancara, Hari Selasa 20 Januari 2022, Ibu Rohimah 
Abdul Pandi

mermelukan adanya biaya. Itulah sebabnya masalah pembiayaan ini harus dimulai dari pembuatan planning sampai dengan pelaksanannya. ${ }^{27}$

c. Tenaga administrasi bagian umum

Kegiatan tenaga administrasi pada bagian ini merupakan salah satu bentuk pelayanan yang diberikan oleh tenaga administrasi untuk mengelola dalam hal yang berkaitan dengan fasilitas sekolah sertasarana prasarananya. MTs. Hidayatul Muhsinin memiliki fasilitas maupun sarana prasarana yang ternilai cukup. Keluhan-keluhan dari orang tua, siswa, maupun guru bukan dari persoalan ketidak nyamanan, melainkan ada sedikit kerusakan pada fasilitas yang digunakan. Penjelasan tersebut terlihat dari hasil observasi yang dilakukan penulis dan hasil wawancara dengan kepala sub bidang umum di MTs. Hidayatul Muhsinin.

\section{Peran Tenaga Administrasi dalam Peningkatan Mutu Layanan}

Sebagai tenaga administrasi sekolah/madrasah di jenjang pendidikan dasar dan menengah atau yang sering dikenal dengan tenaga tata usaha sekolah/madrasah dalam proses pembelajaran sangat diperlukan. Berdasarkan observasi dan wawancara oleh penulis, tenaga kependidikan mencakup yaitu tenaga administrasi, laboran, pustakawan, dll. Namun di dalam penilitian ini hanya berfokus kepada peran tenaga administrasi sekolah. Sebagian besar program kerja tenaga administrasi adalah untuk membantu mensukseskan tujuan sekolah. Hal ini diperkuat dengan pendapat kepala madrasah mengenai peran tenaga administrasi bahwa peran tenaga administrasi merupakan salah satu hal yang sangatberpengaruh bagi sekolah. Kepala madrasah tersebut lebih jelasnya mengemukakan:

"Manfaat yang pertama dirasakan yaitu tidak terhambatnya pendidikan di sekolah ini atau selalu berjalan lancar, karena dapur sekolah terciptadari wujud kinerja tenaga administrasi yang mengurus data perlengkapan sekolah. Para tenaga administrasi benar-benar membantusecara teknis sekolah. ${ }^{28}$

Dibutuhkan kompetensi dan keterampilan yang menunjang di bidang administrasi. Sebagai tenaga administrasi di jenjang pendidikan dasar dan menengah dalam proses pembelajaran sangat diperlukan demi terciptanya sekolah yang bermutu. Berkenaan dengan hal tersebut peran tenaga administrasi sangatlah penting untuk mendukung kelancaran dan kesuksesan tata administrasi sekolah. Adapun peranan yang dilakukan oleh tenaga administrasi tidak hanya dijalankan oleh bagian tenaga administrasi saja, hal itu diungkapkan oleh humas, bahwa:

"Hubungannya tenaga administrasi, dalam hal ini Kabag Tata Usaha, berdasarkan surat keputusan Lembaga Pendidikan Islam Hidayatul Muihsinin tentang organisasi dan tata laksana madrasah yang tertuang dalam lampiran (struktur organisasi) sama-sama bertanggungjawab langsung pada kepala sekolah. Yang berikutnya, sama-sama memberikan pelayanan kepada stakeholder. ${ }^{29}$

Dari pemapaparan di atas, tenaga administrasi dalam berupaya meningkatkan mutu layanan administrasi melakukan kerja sama atau bermitra. Berdasarkan penjelasan di atas tugas yang dilakukan oleh tenaga administrasi menurut beberapa pengguna jasa, sudah memiliki kompetensi \& kualifikasi yang memadai serta berkompeten di bidangnya. Hal ini dibuktikan dengan kepuasan yang dirasakan oleh pengguna jasanya dalam berbagai hal di bidang akademik hingga keuangan dan pegawai.

\section{Hambatan dalam Meningkatkan Mutu Layanan Administrasi}

\footnotetext{
${ }^{27}$ Ngalim Purwanto, Administrasi dan Supervisi Pendidikan, (Bandung: Remaja Rosdakarya, 2005), 21.

${ }^{28}$ Wawancara hari selasa, 20 Januari 2022, Bpk Masruji, S.Sos

${ }^{29}$ Wawancara Hari selasa 20 Januari 2022, Bpk Puliman (Humas)
} 
Dalam pelaksanaan meningkatkan mutu layanan administrasi, sebagai madrasah swasta yang tergolong baik dan berakreditasi B, masih adanya beberapa hambatan, bagian keuangan \& kepegawaian mengungkapkan bahwa:

"Belum tersedianya sistem database kepegawaian secara komprehensif. Ada kendala saat mati listrik pada finger print yang membuat tidak bisa mendeteksi absensi secara optimal. Partisipasidalam kegiatan yang terkait dengan jobdesk bersifat insidensial. Perjuangan SPP yang tidak dinaikkan membuat sedikit kesulitan dalam RAPBS. Masih adanya wali siswa yang lupa bayar maupun nunggak pembayaran SPP.”

Dari pihak tenaga administrasi sudah mengungkapkan beberapa kendala dalam meningkatkan mutu layanan administrasi dari berbagai macam sub bagian di madrasah. Namun dari pihak guru, hambatan yang dirasakan menurut guru Sejarah Kebudayaan Islam tersebut bahwa:

"Kendala yang dirasakan dalam layanan administrasi masih tidak terlalu cepat, misalnya: pendataan nomor urut dan print out data pendidik dan tenaga kependidikan, dalam faktor lain peralatan sekolah yang sudah tidak layak pakai tidak segera ditindak lanjuti karena terkait anggaran. ${ }^{30}$

Kemudian pihak guru yang lain menambahkan:

"Untuk keberadaan ruang tenaga administrasi masih terasa lelah jika harus bolak-balik apalagi kondisi guru perempuan dalam keadaan hamil dan fasilitas untuk guru masih kurang karena dilihat dari jumlah guru yang banyak. ${ }^{31}$

Berdasarkan pemaparan dan hasil wawancara di atas, dari pihak tenaga administrasi dan para pengguna jasa mengungkapkan bahwa hambatan-hambatan yang dialami berbeda. Hambatan yang dialami antara lain pengumpulan berkas dari pihak orang tua maupun siswa tidak selalu berjalan tepat waktu, sistem database kepegawaian belum menerapkan secara komprehensif, layanan yang diberikan masih belum terbilang cepat, dan keberadaan ruangan tenaga administrasi yang selalu berpindah-pindah dan lainnya.

\section{Strategi dalam Meningkatkan Mutu Layanan Administrasi}

Dalam meningkatkan mutu layanan administrasi diperlukan strategi yang dilakukan agar tujuan sekolah tercapai. Terdapat beberapa pendapat mengemukakan strategi peningkatan mutu layanan administrasi sebagai berikut:

Menurut Kepala Madrasah strategi untuk memotivasi kinerja para tenaga administrasi dengan cara:

"Motivasi untuk para tenaga administrasi, secara komunikatif menegaskan bahwa mereka adalah bagian yang tak terpisahkan berlangsungnya proses pendidikan dan memastikan bahwasannya semua hal tersebut berjalan dengan baik, karena fungsi dari pegawai tenaga administrasi ialah untuk memberikan pelayanan terhadap terselenggaranya proses pendidikan. ${ }^{32}$

Menurut kepala bagian tenaga administrasi strategi untuk meningkatkan layanan dari pihak tenaga administrasi bahwa:

"Kan semua orang ada yang ikut diklat ada yang enggak, tapi yang sering ikut, pernah semua sih kayaknya, kalau yang kita anggap diklat itu pas rapat kerja, itu termasuk pelatihan juga, cuma selebihnya yang menunjukkan itu sebagai pelatihan belum ada, di setiap rapat kerja mengadakan narasumber dari

\footnotetext{
30 Wawancara Hari rabu 21 Januari 2022 Guru bpk Saifullah

31 Wawancara Hari rabu 21 Januari 2022 Guru bpk M.Nasir

32 Wawancara Kepsek Masruji, Hari Selasa 20 Januari 2022
} 
berbagai macam kalangan dalam rangka raker, cuma kita (pihak sekolah) tidak mengeluarkan sertifikat. Jadi hanya keterlibatan saja. ${ }^{33}$

Dari pemaparan di atas adanya sinkronisasi antara motivasi dari kepala Madrasah yang mana kepala bagian tenaga administrasi telah mengadakan pendidikan dan pelatihan kepada para tenaga administrasi, namun pelatihan yang diberikan tersebut diadakan di dalam sekolah bersamaan dengan rapat kerja atau dikenal $O n$ The Job Training.

Dari beberapa penjelasan di atas dapat diketahui bahwa tenaga administrasi menerapkan berbagai macam strategi untuk meningkatkan layanan administrasi. Yang mana strategi tersebut berdampak pada setiap pengguna jasa di madrasah. Pihak kepala madrasah secara rutin tidak luput untuk memotivasi para tenaga administrasi dan pegawai lainnya. Kepala bagian tenaga administrasi mengupayakan pengadaan diklat secara rutin di dalam maupun diluar sekolah.

\section{Temuan Hasil Penelitian}

Pengelolaan administrasi yang dilakukan oleh tenaga administrasi di MTs.Hidayatul muhsinin terdapat pada 3 bagian. Pertama, Bidang pendidikan \& pengajaran. Kedua, Bidang keuangan \& kepegawaian, dan ketiga, Bagian umum. Bidang pendidikan \& pengajaran berperan untuk menangani hal-hal yang berkaitan dengan proses kegiatan belajar mengajar, bagian keuangan \& kepegawaian menangani hal-hal yang berkaitan dengan pemasukan pengeluaran biaya serta data pegawai, pada bidang umum menangani hal-hal yang berkaitan dengan menjaga memelihara dan mengadakan fasilitas maupun sarana prasarana. Untuk lebih jelasnya bagaimana peran pada masing-masing tenaga administrasi dipaparkan sebagai berikut:

Pada bagian pendidikan \& pengajaran mengemban tugas: pembuatan kohor, koordinasi dengan Wakakur wali kelas yang belum melaporkan perkembangan siswa (absensi), koordinasi dengan Wakakur wali kelas yang belum menyerahkan daya serap dan rekap nilai, menyusun laporan Dikjar, pelayanan terhadap masyarakat umum/instansi terkait, melayani/menginformasikan kepada tamu yang sedang mengadakan studi banding, melayani/menginformasikan kepada mahasiswa yang mengadakan riset.

Pada bagian keuangan \& kepegawaian mengemban tugas: menyiapkan laporan bulanan dan laporan pertanggungjawaban akhir tahun pelajaran, mengkoordinir pelaksanaan tugas dan pengelolaan administrasi kepegawaian dan keuangan yang menjadi tanggungjawabnya, melakukan pemeriksaan hasil verifikasi pembukuan dan pelaporan sebelum dilakukan pengesahan, menerima pengajuan realisasi anggaran dan mempersiapkan rincian rencana pengambilan uang di Bank dengan melampirkan semua bukti fisik pendukungnya, memeriksa kembali rincian penggunaan uang yang telah dikeluarkan, menyaksikan dan memeriksa cash opname dan rekonsiliasi keuangan madrasah, melakukan verifikasi terhadap semua bukti transaksi penerimaan keuangan, menyiapkan laporan akuntansi keuangan dan realisasi anggaran secara rutin perbulan.

Pada bagian umum mengemban tugas: mengkoordinir pendataan barang-barang yang masih baik/rusak, mengontrol petugas kebersihan pada saat jam tugas, membantu Kepala Tata Usaha dalam merencanakan kebutuhan sarana dan prasana sekolah, mengkoordinir progam stock off name sarana prasarana sekolah, menyusun progam pemeliharaan saranadan prasarana sekolah mencakup $6 \mathrm{~K}$, memantau dan melaporkan pelaksanaan progam pemeliharaan $6 \mathrm{~K}$, mengkoodinir kegiatan perbaikan sarana dan prasarana, melaksanakan tugas lain yang ditentukan oleh Kepala Bagian Tata Usaha.

\footnotetext{
${ }^{33}$ Wawancar Kepala TU
} 
Jadi fungsi tenaga administrasi sekolah sebagai pelaksana teknis admnistrasi sekolah dalam melaksanakan pelaksana urusan administrasi kepegawaian; pelaksana urusan administrasi keuangan; pelaksana urusan administrasi saranadan prasarana; pelaksana urusan administrasi hubungan sekolah dengan masyarakat; pelaksana urusan administrasi persuratan dan pengarsipan; pelaksana urusan administrasi kesiswaan; pelaksana urusan administrasi kurikulum yang memiliki kompetensi, keterampilan dan pengetahuan agar mencapai tujuan yang sudah ditetapkan secara efektif dan efisien.

\section{Kesimpulan}

Aspek paling penting yang menentukan dalam keberhasilan sebuah satuan lembaga pendidikan yaitu terselenggaranya seluruh aktivitas organisasi sekolah secara efisien. Peranan tenaga administrasi sendiri didalam sekolah sangatlah berarti dalam menunjang kelancaran serta kesuksesan tata administrasi sekolah. Maka dari itu administrasi harus mampu menjalankan tugas dan fungsinya secara baik sehingga diperlukan kompetensi serta keahlian yang mendukung dibidang administrasi. Berdasarkan hasil penelitian yang telah dipaparkan, maka dapat dijelaskan bahwa peran tenaga administrasi dalam meningkatkan mutu layanan administrasi terdapat 3 subbagian yaitu: pendidikan \& pengajaran, keuangan \& kepegawaian, dan umum. Hal ini dapat terlihat dari:

1. Kinerja tenaga administrasi dengan strategi yang dilakukan yaitu memudahkan sistem pembayaran SPP yang sudah diterapkan sejak 2008, dan memelihara serta mengelola fasilitas sarana prasana sekolah. Pengintegrasian program dari para tenaga administrasi dengan kegiatan sehari hari di sekolah masih terus berjalan meskipun terdapat beberapahambatan dalam pelaksanaan.

2. Hambatan-hambatan yang dihadapi sekolah dalam mengelola layanan administrasi yaitu gudang arsip belum optimal, sistem database secara komprehensif belum diterapkan dan penyusunan RAPBS masih terdapat kesulitan terkait SPP yang tidak dinaikkan, fasilitas yang ada masih terdapat keluhan dari pengguna jasa namun keluhan-keluhan tersebut tidak selalu ditangani secara cepat karena terkait jumlah tenaga administrasi.

3. Upaya yang dilakukan untuk menangani beberapa hambatan tersebut ialah memberikan surat pemberitahuan kepada orang tua siswa agar mengumpulkan berkas dengan segera, menaikkan pembayaran biaya SPP kepada siswa baru untuk menutupi sistem SPP yang tidak dinaikkan, jadi setiap angkatan membayar SPP dengan biaya yang berbeda, strategi selanjutnya diterapkannya sistem pengontrolan kondisi fasilitas sekolah.

\section{Daftar Kepustakaan}

Anselm Strauss, dkk, Dasar-Dasar Penelitian Kualitatif, Yogyakarta: Pustaka Belajar, 2009

Alkaf, Nuraida Khalid, Metodologi Penelitian Pendidikan, Tangerang: Islamic Reserch Publising, 2009

Abu Ahmadi dan Nur Uhbiyati, Imu Pendidikan, Jakarta: PT. Rineka Cipta, 2001,

Anonim, Pengelolaan Laboratorium Fisika Sekolah Menengah Atas, Jakarta, 2007

Direktorat Jenderal Manajemen Pendidikan Dasar dan Menengah

Engkoswara, Kecendrungan kehidupan di Indonesia menjelang tabun 2000 dan Implikasinya terbadap sistem pendidikan, Jakarta: Intermedia, 1986

Kepmendiknas No. 053/U/2001 Tentang Pedoman Penyusunan Standar Pelayanan Minimal Penyelenggaraan Persekolahan Bidang Pendidikan Dasar dan Menengah

Mappaenre, Ahmad, Dasar-Dasar Ilmu Administrasi Dan Manajemen. Makassar: Badan Penerbit Universitas Negeri Makassar, 2009.

Muniarti AR \&Nasir Isman, Implementasi Manajemen Stratejik dalam Memberdayakan Sekolah. Bandung: Cipta Pustaka, 2009.

Mohammad Mustari, Manajemen Pendidikan, Jakarta: Raja Grafindo Persada, 2014 
Abdul Pandi

Nasution, Berbagai Pendekatan Belajar Dan Mengajar, Jakarta: Bina Aksara, 1994

Nana Syaodih, Metode Penelitian Pendidikan, Bandung: Remaja Rosdakarya, 2013

Ngalim Purwanto, Administrasi dan Supervisi Pendidikan, Bandung: Remaja Rosdakarya, 2005

Oteng, Sutisna, Administrasi Pendidikan, (Guru \& Administrasi Sekolab). Bandung: Diktat Perkuliahan FKIP-UNPAD, 1979

Purwanto, Ngalim, Imu pendidikan Teoritis dan Praktis, Bandung: Remaja, 2000

Sagala, Syaiful, Kemampuan Profesional Guru dan Tenaga Kependidikan, Bandung: Alfabeta, 2009

Administrasi Pendidikan Kontemporer, Bandung: Alfabeta

Sallis, Edward, Total Quality Management in Education, London, British Library Cataloguing in Publication Data, 1933.

Syarif, Ismed dkk, Administrasi Pendidikan Sekolah Dasar, Jakarta: Rosdakarya, 1976

Sugiyono, Metode Penelitian Kuantitatif Kualitatif dan ReD, Jakarta: Alfabeta, 2011

Sunyoto, Danang, Konsep Dasar Riset Pemasaran dan Perilaku Konsumen, Yogyakarta: CAPS (Center for Academic Publishing. Service), 2014.

The Liang Gie, Administrasi Perkantoran Modern, Yogyakarta: Liberty, 2007 